\title{
Mass and energy balance of the carbonization of babassu nutshell as affected by temperature
}

\author{
Thiago de Paula Protásio(1), Paulo Fernando Trugilho(1), Alfredo Napoli(2), \\ Marcela Gomes da Silva(3) and Allan Motta Couto(1)
}

\begin{abstract}
(1)Universidade Federal de Lavras, Departamento de Ciências Florestais, Caixa Postal 3037, CEP 37200-000 Lavras, MG, Brazil. E-mail: depaulaprotasio@gmail.com, trugilho@dcf.ufla.br, allan_floresta@yahoo.com.br ${ }^{(2)}$ Centre de Coopération Internationale en Recherche Agronomique pour le Développement, Département de Performance des Systèmes de Production et de Transformation Tropicaux, TA B-40/16, 73 Rue Jean-François Breton 3 c 4398, Montpellier, France. E-mail: alfredo.napoli@cirad.fr (3)Universidade Federal Rural da Amazônia, Avenida Tancredo Neves, no 2.501, Caixa Postal 917, CEP 66077-530 Belém, PA, Brazil. E-mail: marcela.gsilva@gmail.com
\end{abstract}

\begin{abstract}
The objective of this work was to evaluate the carbonization yield of babassu nutshell as affected by final temperature, as well as the energy losses involved in the process. Three layers constituting the babassu nut, that is, the epicarp, mesocarp and endocarp, were used together. The material was carbonized, considering the following final temperatures: $450,550,650,750$, and $850^{\circ} \mathrm{C}$. The following were evaluated: energy and charcoal yields, pyroligneous liquid, non-condensable gases, and fixed carbon. The use of babassu nutshell can be highly feasible for charcoal production. The yield of charcoal from babassu nutshell carbonization was higher than that reported in the literature for Eucalyptus wood carbonization, considering the final temperature of $450^{\circ} \mathrm{C}$. Charcoal and energy yields decreased more sharply at lower temperatures, with a tendency to stabilize at higher temperatures. The energy yields obtained can be considered satisfactory, with losses between 45 and $52 \%$ (based on higher heating value) and between 43 and $49 \%$ (based on lower heating value) at temperatures ranging from 450 to $850^{\circ} \mathrm{C}$, respectively. Yields in fixed carbon and pyroligneous liquid are not affected by the final carbonization temperature.
\end{abstract}

Index terms: alternative biomass, charcoal, iron industry, renewable energy.

\section{Balanço de massa e energia da carbonização da casca do coco babaçu em função da temperatura}

Resumo - O objetivo deste trabalho foi avaliar os rendimentos da carbonização da casca do coco babaçu em função da temperatura final, bem como as perdas energéticas envolvidas nesse processo. Foram utilizadas conjuntamente as três camadas constituintes do coco babaçu, ou seja, o epicarpo, o mesocarpo e o endocarpo. $\mathrm{O}$ material foi carbonizado tendo-se considerado as seguintes temperaturas finais: $450,550,650,750$ e $850^{\circ} \mathrm{C}$. Foram avaliados: rendimentos em carvão vegetal e energético, líquido pirolenhoso, gases não condensáveis e carbono fixo. O uso da casca do babaçu pode ser altamente viável para a produção de carvão vegetal. O rendimento em carvão vegetal da carbonização da casca do coco babaçu foi maior que o relatado na literatura para a carbonização da madeira de Eucalyptus, ao se considerar temperatura final de $450^{\circ} \mathrm{C}$. Os rendimentos em carvão e energético diminuíram de forma mais acentuada em temperaturas mais baixas, com tendência de estabilização em temperaturas mais elevadas. Os rendimentos energéticos obtidos podem ser considerados satisfatórios, com perdas entre 45 e $52 \%$ (com base no poder calorífico superior) e entre 43 e $49 \%$ (com base no poder calorífico inferior) para as temperaturas de 450 a $850^{\circ} \mathrm{C}$, respectivamente. Os rendimentos em carbono fixo e líquido pirolenhoso não são afetados pela temperatura final de carbonização.

Termos para indexação: biomassa alternativa, carvão vegetal, siderurgia, energia renovável.

\section{Introduction}

Brazil stands out as the largest producer in the world of pig iron from charcoal (Associação Brasileira de Produtores de Florestas Plantadas, 2012), and Eucalyptus plantations are the main responsible for the supply of this bio-reducer. In 2011, 4,127,781 tons of charcoal were produced (Instituto Brasileiro de
Geografia e Estatística, 2013), of which approximately $65 \%$ were from planted forest (Associação Brasileira de Produtores de Florestas Plantadas, 2012).

However, forest plantations are not able to meet the demand for charcoal from iron industries on a sustainable basis. Furthermore, industries that use charcoal will have to increase the use of this fuel, which comes from sustainable sources, until 2020 (Plano de 
ação para prevenção e controle do desmatamento e das queimadas, 2010). Therefore, researches related to the evaluation of alternative lignocellulosic materials that may be used for charcoal production in iron industries, such as the babassu nutshell, are necessary.

Babassu is considered the largest native oil resource worldwide, with 14,563,000 ha, and occurs naturally in Brazil, mainly in the North and Northeast regions (Babaçu, 1984). It refers to three distinct genera of the Arecaceae family: Scheelea, Attalea, and Orbignya, and the species Orbignya phalerata Mart. is the most common and widespread (Teixeira, 2008).

The residue from the babassu nut (or shell) comprises all three constituent layers of the fruit: epicarp, mesocarp, and endocarp. These layers correspond to approximately $93 \%$ of the total fruit (Babaçu, 1984; Emmerich \& Luengo, 1996; Dias et al., 2012). Therefore, for each ton of babassu nut, there are $930 \mathrm{~kg}$ of residues.

Currently, there are 1,409,016 tons of residues from the babassu nut in Brazil (Dias et al., 2012), which can be used in charcoal production; however, according to estimates by Teixeira (2008), this value may exceed 6 million tons, and the state of Maranhão has the highest potential $(92 \%)$.

The babassu nut charcoal is likely to be used in the iron industry as a direct substitute for metallurgical coke (Silva et al., 1986; Emmerich \& Luengo, 1996), because it solves two factors constraining the use of wood charcoal: low density and low compressive strength (Emmerich \& Luengo, 1996).

However, despite the considerable supply of babassu nut and the demand for charcoal from iron industries in the North and Northeast of Brazil, there are few studies related to the feasibility in the use of this raw material for that purpose. It is known that Eucalyptus plantations are mostly deployed in the South and Southeast of the country (Associação Brasileira de Produtores de Florestas Plantadas, 2012), but the North and Northeast also have iron industries that could use babassu nut charcoal, mitigating the exploitation of native forests and contributing to the increase in the income of extractive communities in the region.

The objective of this work was to evaluate the carbonization yield of babassu nutshell as affected by final temperature, as well as the energy losses involved in this process.

\section{Materials and Methods}

The babassu nut was collected in the rural area of the municipality of Sítio Novo do Tocantins, in the

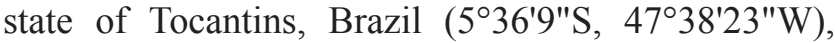
and comes from the extractive exploitation by local communities. The three layers constituting the babassu nut, that is, the epicarp, mesocarp, and endocarp, were used together.

Carbonizations were carried out in an electric oven (muffle) with a water-cooled condenser and a collection vessel for vapors (pyroligneous liquid). About $500 \mathrm{~g}$ of babassu nutshell were used in each assay. The samples were previously oven-dried at $103 \pm 2^{\circ} \mathrm{C}$. The initial temperature of the assay was $100^{\circ} \mathrm{C}$, and the final temperatures were: $450,550,650,750$, and $850^{\circ} \mathrm{C}$, considering a heating rate of $1.67^{\circ} \mathrm{C} \mathrm{min}^{-1}\left(100^{\circ} \mathrm{C} \mathrm{h}^{-1}\right)$. The electric oven was stabilized at the final temperatures for $30 \mathrm{~min}$. The total carbonization time was four, five, six, seven, and eight hours at the temperatures of 450 , $550,650,750$, and $850^{\circ} \mathrm{C}$, respectively.

Four replicates were performed for each final temperature. The procedure used in laboratory carbonizations is similar to that described for wood in the literature (Neves et al., 2011; Protásio et al., 2011, 2013b; Assis et al., 2012; Pereira et al., 2012).

After carbonization, the gravimetric yield in charcoal was calculated by dividing the dry mass of charcoal by the dry mass of babassu nutshell multiplied by 100 , with the following equation: $\mathrm{GYC}=(\mathrm{MC} / \mathrm{MB}) 100$, in which GYC is the gravimetric yield in charcoal (\%); $\mathrm{MC}$ is the dry mass of charcoal (g); and MB is the dry mass of the babassu nutshell $(\mathrm{g})$.

The yield in pyroligneous liquid was calculated by dividing the mass of liquid by the dry mass of the babassu nutshell multiplied by 100 , as in the equation: YPL $=(\mathrm{ML} / \mathrm{MB}) 100$, in which YPL is the yield in pyroligneous liquid (\%); ML is the mass of the liquid $(\mathrm{g})$; and MB is the dry mass of the babassu nutshell $(\mathrm{g})$.

The yield in non-condensable gases was obtained by difference, using the following equation: YNCG $=100-$ GYC - YPL, in which YNCG is the yield in non-condensable gases (\%); GYC is the gravimetric yield in charcoal (\%); and YPL is the yield in pyroligneous liquid (\%).

The proximate analysis was performed in the charcoal samples, in order to determine moisture, volatile matter, ash, and fixed carbon by difference, according to the American Society for Testing 
Materials (ASTM), standard D1762-84 (American Society for Testing Materials, 2007). Therefore, it was possible to obtain the yield in fixed carbon by the product of the gravimetric yield in charcoal and the fixed carbon content of the charcoal, using the equation: $\mathrm{YFC}=(\mathrm{GYC} \times \mathrm{FC}) / 100$, in which YFC is the yield in fixed carbon (\%); GYC is the gravimetric yield in charcoal (\%); and FC is the fixed carbon content of the charcoal (\%).

To calculate the energy yields, it was necessary to determine the higher heating value of charcoal and fresh biomass, according to ASTM E711-87 (American Society for Testing Materials, 2004) in the calorimeter, IKA C-200 (LabControl Instrumentos Científicos Ltda., São Paulo, SP, Brazil). The lower heating value was calculated based on the following equation: $\mathrm{LHV}=[\mathrm{HHV}-(600 \times 9 \mathrm{H}) / 100]$, in which LHV is the lower heating value $\left(\mathrm{kcal} \mathrm{kg}^{-1}\right)$; HHV is the higher heating value ( $\left.\mathrm{kcal} \mathrm{kg}^{-1}\right)$; and $\mathrm{H}$ is the hydrogen content $(\%)$.

The hydrogen content was obtained through an elementar vario micro cube universal analyzer (Biovera, Rio de Janeiro, RJ, Brazil) in duplicate. The samples were crushed and sieved, and the fraction that passed through the 200 mesh sieve and that was retained on the 270 mesh sieve was used. Subsequently, the samples were dried in an oven at $103 \pm 2^{\circ} \mathrm{C}$, and approximately $2 \mathrm{mg}$ were placed in tin capsules and brought to the equipment. The analyzer uses helium and oxygen as carrier and ignition gases, respectively.

The hydrogen contents found, on a dry weight basis, were $3.4,2.8,2.2,1.8$, and $1.6 \%$ for charcoals produced in the final temperatures of $450,550,650$, 750 , and $850^{\circ} \mathrm{C}$, respectively.

Therefore, the energy yields $\left(E_{1}\right.$ and $\left.E_{2}\right)$ were obtained based on the HHV and LHV equations: $\mathrm{EY}_{1}=\mathrm{GYC}\left(\mathrm{HHV}_{\text {charcoal }} / \mathrm{HHV}_{\text {fresh }}\right)$ and $\mathrm{EY}_{2}=\mathrm{GYC}\left(\mathrm{LHV}_{\text {charcoal }} / \mathrm{LHV}_{\text {fresh }}\right)$, in which GYC is the gravimetric yield in charcoal (\%); $\mathrm{HHV}_{\text {charcoal }}$ and $\mathrm{LHV}_{\text {charcoal }}$ are the higher and lower heating values of charcoal ( $\mathrm{kcal} \mathrm{kg}^{-1}$ ), respectively; and $\mathrm{HHV}_{\text {fresh }}$ and $\mathrm{LHV}_{\text {fresh }}$ are the higher and lower heating values of fresh biomass ( $\left.\mathrm{kcal} \mathrm{kg}^{-1}\right)$.

Univariate variance analyses were performed, as well as adjustments of linear regression models, using a completely randomized design with four replicates for all calculated yields and considering the effect of the final carbonization temperature as a variation factor.

A test for homogeneity of variances was conducted (Bartlett's test, at $5 \%$ probability) preliminary to analysis of variance. In addition, it was possible to determine the normality of residues by the Shapiro-Wilk test, at $5 \%$ probability. For all the parameters evaluated, deviations from these analysis' assumptions were not observed.

Principal component analysis was also performed in order to group similar temperatures, based on the carbonization yields of babassu nutshell. The relationship between the variables (multicollinearity) is not a problem in this analysis. Therefore, only standardized means (with unit variance) of all yields were considered. This procedure allows higher accuracy in the analysis.

All statistical analysis was performed using the $\mathrm{R}$ software, version 3.0.1 (R Development Core Team, 2013) through the packages ExpDes (Ferreira et al., 2013) and Stats (R Development Core Team, 2013).

\section{Results and Discussion}

The yield in fixed carbon, which expresses the amount of carbon present in fresh biomass and retained in charcoal, was not influenced by the final carbonization temperature (Table 1). The experimental coefficient of variation found for this parameter was $1.20 \%$.

This yield is obtained by the product of the fixed carbon content and the gravimetric yield in charcoal, and these two variables have a negative correlation (Protásio et al., 2011; Reis et al., 2012). Therefore, for yield calculation in fixed carbon, proportionality was kept, in which the yield in charcoal tends to decrease and the fixed carbon content tends to increase with the final carbonization temperature (Trugilho \& Silva, 2001; Demirbas, 2004; Titiladunayo et al., 2012; Vieira et al., 2013).

The average yield in fixed carbon found for babassu nutshell was $25.8 \%$, that is, the carbonization of $100 \mathrm{~kg}$ of absolutely dry shell provides $25.8 \mathrm{~kg}$ of fixed carbon. This value is similar to that obtained for the carbonization of wood from Eucalyptus clones at 34,42 , and 68 months, of $25.8,25.2$, and $25.2 \%$, respectively (Neves et al., 2011; Assis et al., 2012; Protásio et al., 2013b), and shows the potential of 
fixed carbon production through the slow pyrolysis of babassu nut residues.

The yield in pyroligneous liquid, which consists of a complex mixture of pyroligneous acid and insoluble tar, also showed no significant differences for the final carbonization temperatures considered, and a low experimental coefficient of variation was observed $(4.50 \%)$ (Table 1$)$. The average yield in pyroligneous liquid found for babassu nutshell was $45.7 \%$. This result can be explained by the chemical constitution of the babassu nut (Protásio et al., 2014) and by the differential resistance of cell wall components to thermal degradation.

Cellulose and hemicelluloses (holocellulose) are the main constituents of biomass, responsible for gas production during pyrolysis, since they have a low resistance to thermal degradation (Yang et al., 2007) and make up the largest cell wall fraction (Protásio et al., 2013a, 2014). Hemicelluloses are degraded at temperatures between 220 and $315^{\circ} \mathrm{C}$, and cellulose, between 315 and $400^{\circ} \mathrm{C}$ (Yang et al., 2007), that is, at temperatures below those used in the carbonization of babassu nutshell. Protásio et al. (2014) verified a maximum rate of thermal decomposition for babassu nutshell at $303^{\circ} \mathrm{C}$, validating the discussion held.

However, despite losing mass at lower temperatures, between 150 and $900^{\circ} \mathrm{C}$ (Yang et al., 2007), lignin has a much lower loss rate when compared to other chemical constituents of plant biomass (Pereira et al., 2012; Burhenne et al., 2013).

The average yield in pyroligneous liquid obtained for the carbonization of babassu nutshell is similar to that found in the literature for Eucalyptus clones at 34 and 42 months, of 43.0 and $41.4 \%$, respectively (Assis et al., 2012; Protásio et al., 2013b). This was possibly due to the similarity in the holocellulose content of Eucalyptus wood and babassu nutshell.

The babassu nutshell analyzed in the present study shows total lignin and holocellulose levels of 31 and 62\%, respectively (Protásio et al., 2014). For commercial clones of Eucalyptus spp., Neves et al. (2011) reported average total lignin and holocellulose contents of 30 and $66 \%$, respectively. The same authors found an average yield in pyroligneous liquid of $45.4 \%$ for these clones, i.e., similar to that obtained in the present study for the carbonization of babassu nutshell in the final temperature of $450^{\circ} \mathrm{C}(45.7 \%)$. This result can be attributed to the chemical similarity between the studied biomass and the wood from Eucalyptus spp. clones, as well as to the similarity in the process used in pyrolysis.

A significant effect of the final carbonization temperature on gravimetric yields was observed in charcoal, non-condensable gases, and energy yields based on HHV and LHV. The experimental coefficients of variation found for these variables were: 0.92, $8.91,1.38$, and $1.36 \%$, respectively. Therefore, the final carbonization temperatures can be analyzed to maximize the productivity of high-quality charcoal for use in blast furnaces and with the lowest energy losses involved in this process.

The gravimetric yield in charcoal presented a marked decrease, with an increase in the final carbonization temperature. In the temperatures of 750 and $850^{\circ} \mathrm{C}$, a tendency for stabilization of the gravimetric yield in charcoal was observed (Figure 1), which can be credited to a severe thermal degradation of holocellulose at temperatures below $400^{\circ} \mathrm{C}$. At temperatures above $600^{\circ} \mathrm{C}$, the main volatilization phase of $\mathrm{H}_{2}$, which has a low molecular weight, occurs (Yang et al., 2007; Amutio et al., 2012), justifying the tendency for the yield in charcoal to stabilize.

The quadratic model better described the effect of the final carbonization temperature on charcoal yield; moreover, it was statistically significant and showed all significant coefficients. By obtaining the first derivative of this quadratic function and equating the result to zero, it is possible to determine the curve inflection point at $830^{\circ} \mathrm{C}$, which, in this case, is a minimum point,

Table 1. Yield in fixed carbon (YFC) and in pyroligneous liquid (YPL) as affected by the final carbonization temperature of the babassu nutshell.

\begin{tabular}{|c|c|c|c|c|c|c|c|c|}
\hline Yield & $450^{\circ} \mathrm{C}$ & $550^{\circ} \mathrm{C}$ & $650^{\circ} \mathrm{C}$ & $750^{\circ} \mathrm{C}$ & $850^{\circ} \mathrm{C}$ & General mean & F-value & p-value \\
\hline$\overline{\mathrm{YFC}(\%)}$ & $25.5(0.52)^{(1)}$ & $26.1(0.21)$ & $26.1(0.33)$ & $25.7(0.18)$ & $25.8(0.14)$ & 25.8 & $2.790^{\mathrm{ns}}$ & 0.0648 \\
\hline YPL (\%) & $44.9(0.69)$ & $46.1(1.26)$ & $45.8(1.77)$ & $45.6(3.12)$ & $46.0(2.50)$ & 45.7 & $0.249^{\mathrm{ns}}$ & 0.9058 \\
\hline
\end{tabular}

${ }^{(1)}$ Standard deviation in parentheses. ${ }^{\mathrm{ns}}$ Nonsignificant by the $\mathrm{F}$ test, at $5 \%$ probability. 
since the second derivative shows that the function is positive definite.

For the final temperature of $450^{\circ} \mathrm{C}$ and rate of $100^{\circ} \mathrm{C} \mathrm{h}^{-1}$, the gravimetric yield in charcoal for Eucalyptus clones at 34, 42, and 68 months is, on average, 32\% (Neves et al., 2011; Assis et al., 2012; Protásio et al., 2013b), that is, approximately $9 \%$ lower than that observed for babassu nutshell $(\mathrm{GYC}=35 \%)$. This result can be explained by the qualitative differences of the lignin found in the babassu nut, compared to Eucalyptus wood, and shows the feasibility of charcoal production from this lignocellulosic material.

The lignin found in hardwoods (eudicotyledonous angiosperms) has higher amounts of syringyl precursor units (trans-sinapyl alcohol) than guaiacyl (trans-coniferyl alcohol) in varying proportions (Nunes et al., 2010; Castro et al., 2013; Pereira et al., 2013). However, the lignin found in monocotyledonous angiosperms, such as babassu, is composed of syringyl, guaiacyl, and coumaryl units (trans-p-coumaric alcohol), and syringyl is present in smaller amounts (Nowakowski et al., 2010).

As reported by Pereira et al. (2013) and Protásio et al. (2014), the basic difference between the types of lignin is the amount of methoxyl groups and the amount of C-C bonds on the aromatic ring. The absence of methoxyl groups in the structure of coumaryl lignin enables a higher lignin condensation, due to an increase in $\mathrm{C}-\mathrm{C}$ bonds with another coumaryl unit (Protásio et al., 2014). Therefore, the more coumaryl units in the lignin

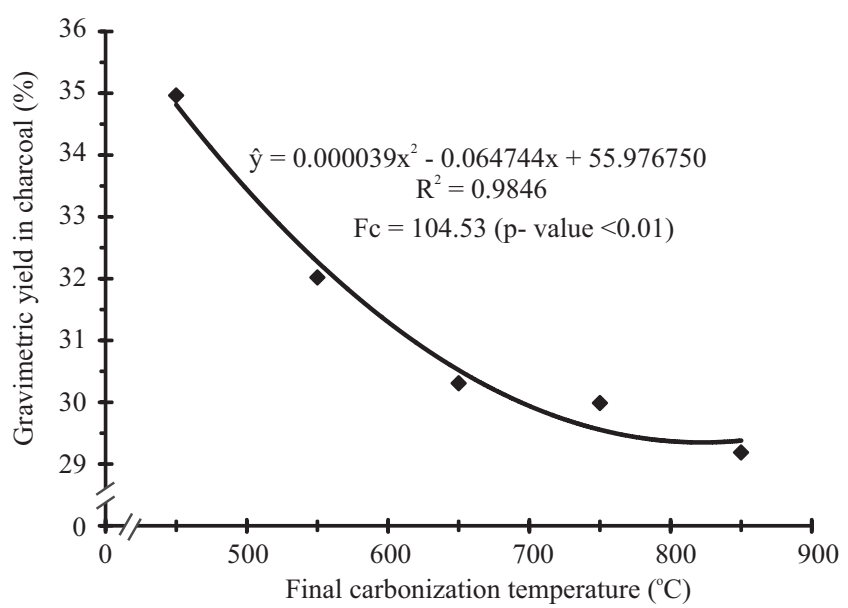

Figure 1. Gravimetric yield in charcoal of the babassu nutshell residues as affected by the final carbonization temperature. macromolecule, the greater will be the condensation of the molecule, i.e., the greater the number of bonds between the aromatic rings and the greater the energy required to break these chemical bonds. Consequently, biomass will be thermally more stable and the yield in charcoal will be higher. Based on this discussion, it can be stated that the highest gravimetric charcoal yield observed for babassu nutshell can be attributed to a higher condensation and thermal stability of the lignin molecule.

The simple linear model best described the influence of the final carbonization temperature on yield in non-condensable gases (Figure 2). These results are an indicative that, for each $1{ }^{\circ} \mathrm{C}$ increase in temperature, an increase of approximately $0.012 \%$ occurs in yield in non-condensable gases. The quadratic model was not significant by the $\mathrm{F}$ test ( $\mathrm{p}$-value $=0.3160$ ), at $5 \%$ probability, proving the validity of the fit of the simple linear regression model.

As temperature rises, the organic constituents of biomass are degraded, volatilized, and produce by-products; a gas fraction is condensed and a smaller quantity is released to the atmosphere. The main components of these non-condensable gases are $\mathrm{CO}$, $\mathrm{CO}_{2}, \mathrm{CH}_{4}, \mathrm{H}_{2}$, and low molecular mass hydrocarbons (Yang et al., 2007; Amutio et al., 2012).

The lower the yield in non-condensable gases, the lower will be the emission of fuel gases, as well as of gases causing the greenhouse effect in the atmosphere. In this context, in order to mitigate the effects of these emissions, it is possible to choose the

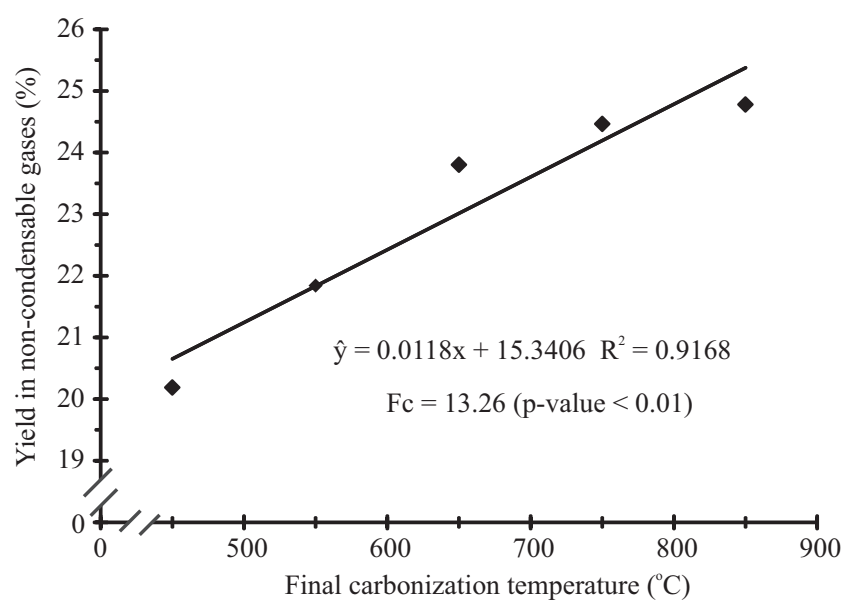

Figure 2. Yield in non-condensable gases of the carbonization of babassu nutshell residues.

Pesq. agropec. bras., Brasília, v.49, n.3, p.189-196, mar. 2014 DOI: 10.1590/S0100-204X2014000300005 
complete combustion of gases from carbonization and to emit only $\mathrm{CO}_{2}$ and $\mathrm{H}_{2} \mathrm{O}$, given that the plants can absorb carbon dioxide and turn it into biomass by the photosynthetic process during their growth. The use of babassu nut charcoal could contribute to the preservation of native forests and reduce $\mathrm{CO}_{2}$ emissions, since the palm tree is not cut, in contrast to what happens in the conventional production of wood charcoal (Emmerich \& Luengo, 1996).

For the temperatures of $500,600,700,800$, and $900^{\circ} \mathrm{C}$, Vieira et al. (2013) reported yield in gases of $23,29,22,24$, and $29 \%$, respectively, for the carbonization of E. microcorys wood. The obtained yield is higher than that found for the charcoal from babassu nutshell, of 20, 22, 24, 24, and 25\% (Figure 2) for the temperatures of $450,550,650,750$, and $850^{\circ} \mathrm{C}$, respectively.

Protásio et al. (2013b) observed an average yield in gases of $27 \%$ for Eucalyptus sp. clones at 42 months of age, given the final carbonization temperature of $450^{\circ} \mathrm{C}$. For the same final carbonization temperature, Neves et al. (2011) found an average yield in gases of $26 \%$ for Eucalyptus sp. clones at 68 months. It is worth mentioning that these authors used the same experimental procedure as the one adopted in the present study. These results can be considered advantageous and reinforce the potential of the studied residual biomass for charcoal production with less environmental impact, as discussed earlier.

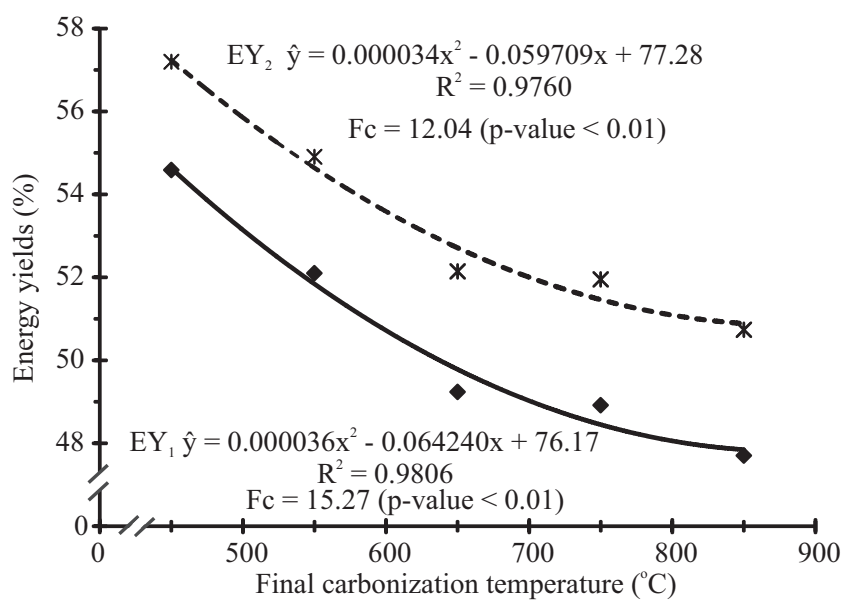

Figure 3. Energy yields as affected by the final carbonization temperature of the babassu nutshell residues.
Quadratic regression models best described the effect of the final carbonization temperature on energy yields and were significant by the $\mathrm{F}$ test (Figure 3 ). All model coefficients were also significant by the $t$ test. The tendency was similar to that found for the gravimetric yield in charcoal, since charcoal productivity is considered in the calculations of these energy efficiencies.

The calculated energy yield based on LHV was higher than that based on HHV (Table 2). This may be due to the volatilization of the hydrogen present in biomass during pyrolysis and to a higher carbon concentration in the charcoal. Protásio et al. (2013a) observed a hydrogen content of $6.3 \%$ in the wood from Eucalyptus clones, and, when the same wood was carbonized, considering the final temperature of $450^{\circ} \mathrm{C}$, the authors reported a hydrogen content of $3.1 \%$ in the charcoal.

Therefore, HHV and LHV in charcoal tend to be similar, and the ratio between LHV in charcoal and fresh biomass is higher than the ratio between HHV in these fuels (Protásio et al., 2013a, 2013b). LHV is calculated on a dry basis and does not consider the amount of energy required to evaporate the water formed by the hydrogen contained in the material.

The energy yields obtained can be considered satisfactory, with losses between 45 and $52 \%$ (based on HHV) and between 43 and 49\% (based on LHV) at temperatures ranging from 450 to $850^{\circ} \mathrm{C}$, respectively. However, fuel gases derived from carbonization can be reused in power generation and contribute decisively to increase the efficiency of converting biomass into charcoal.

The lower temperatures $\left(450\right.$ and $\left.550^{\circ} \mathrm{C}\right)$ showed higher yields in charcoal with the lowest energy losses, and the opposite situation was found for the

Table 2. Higher heating value (HHV) and lower heating value (LHV) of fresh biomass and charcoals of the babassu nutshell residues.

\begin{tabular}{lcccc}
\hline Biofuels & $\begin{array}{c}\mathrm{HHV} \\
\left(\mathrm{MJ} \mathrm{kg}^{-1}\right)\end{array}$ & $\begin{array}{c}\text { LHV } \\
\left(\mathrm{MJ} \mathrm{kg}^{-1}\right)\end{array}$ & $\begin{array}{c}\mathrm{HHV}_{\text {charcoal }} / \mathrm{HHV}_{\text {fresh }} \\
\text { Fresh biomass }\end{array}$ & $\begin{array}{c}\mathrm{LHV}_{\text {charcoal }} \\
\mathrm{LHV}_{\text {fresh }}\end{array}$ \\
\hline Charcoal $450^{\circ} \mathrm{C}$ & $28.47(0.10)^{(1)}$ & $17.16(0.09)$ & - & - \\
Charcoal $550^{\circ} \mathrm{C}$ & $30.06(0.39)$ & $28.07(0.17)$ & 1.56 & 1.64 \\
Charcoal $650^{\circ} \mathrm{C}$ & $29.93(0.22)$ & $29.44(0.23)$ & 1.62 & 1.72 \\
Charcoal $750^{\circ} \mathrm{C}$ & $30.14(0.27)$ & $29.73(0.27)$ & 1.63 & 1.73 \\
Charcoal $850^{\circ} \mathrm{C}$ & $30.19(0.60)$ & $29.83(0.58)$ & 1.63 & 1.74 \\
\hline
\end{tabular}

${ }^{(1)}$ Standard deviation in parentheses. 
temperatures of 750 and $850^{\circ} \mathrm{C}$ (Figure 4). The last two carbonization temperatures can be considered similar and produced the highest amount of gases. This result can be attributed primarily to yields in gas, in charcoal, and in energy, because these original variables have the most significant eigenvectors for the first principal component.

The three main components obtained explained $99.9 \%$ of the total variance in the dataset. Therefore, the most relevant information of the original sample data is contained in these three components (Figure 4). The first principal component showed the largest eigenvalue and, consequently, the highest proportion of explained variance (79\%), and can be considered as a performance index of carbonization. It was observed that the eigenvectors associated with the variables $\mathrm{GYC}, \mathrm{EY}_{1}, \mathrm{EY}_{2}$, and YNGC were 0.4573 , $0.4467,0.4461$, and -0.4383 , respectively. For this reason, the higher the scores of this latent variable, the higher will be the energy and productive carbonization performances.

Therefore, in order to obtain higher yields in charcoal and to decrease the carbonization-related energy expenditure, the final temperature of $750^{\circ} \mathrm{C}$ can

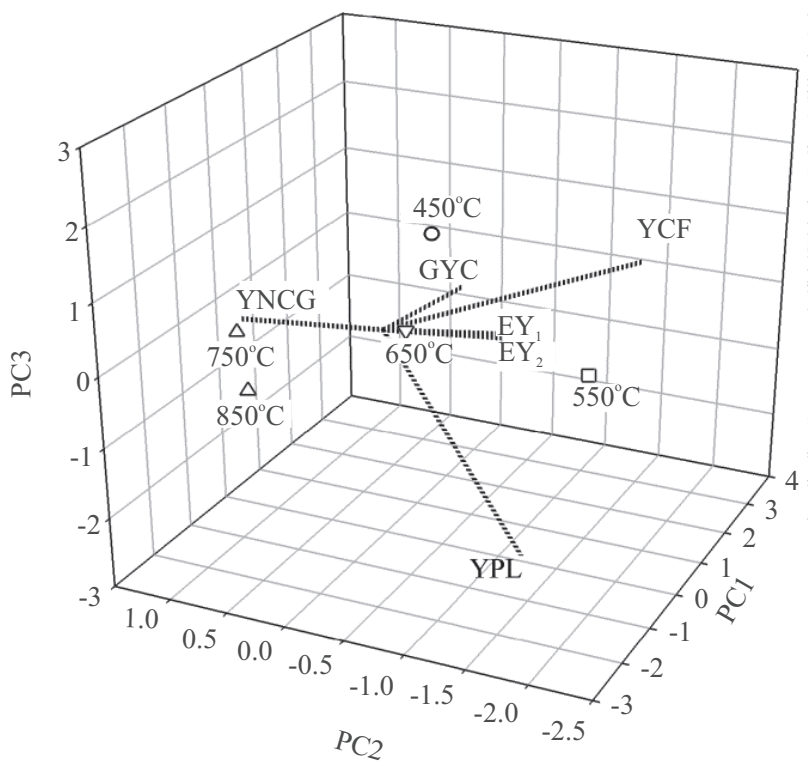

Figure 4. Scores and eigenvectors of principal components one (PC1), two (PC2), and three (PC3). GYC, gravimetric yield in charcoal; $\mathrm{EY}_{1}$ and $\mathrm{EY}_{2}$, energy yields 1 and 2, respectively; YPL, yield in pyroligneous liquid; YNCG, yield in non condensable gases; YFC, yield in fixed carbon. be used instead of $850^{\circ} \mathrm{C}$. The temperature of $650^{\circ} \mathrm{C}$ can be considered intermediate in relation to the others.

\section{Conclusions}

1. The use of babassu nutshell can be highly feasible for charcoal production.

2. Charcoal and energy yields are lower at low temperatures, with a tendency to stabilize at higher temperatures.

3. Yields in fixed carbon and pyroligneous liquid are not affected by the final carbonization temperature.

4. The temperatures of 750 and $850^{\circ} \mathrm{C}$ produce charcoal with similar yields, and the temperature of $650^{\circ} \mathrm{C}$ produces charcoal with intermediate yields.

\section{Acknowledgements}

To Conselho Nacional de Desenvolvimento Científico e Tecnológico (CNPq), for financial support and fellowship (processes 132431/2013-0 and 141439/2014-9, respectively).

\section{References}

AMERICAN SOCIETY FOR TESTING MATERIALS. ASTM D1762-84: standard test method for chemical analysis of wood charcoal. West Conshohocken: ASTM International, 2007. 2p.

AMERICAN SOCIETY FOR TESTING MATERIALS. ASTM E711-87: standard test method for gross calorific value of refuse-derived fuel by the bomb calorimeter. West Conshohocken: ASTM International, 2004. 8p.

AMUTIO, M.; LOPEZ, G.; ARTETXE, M.; ELORDI, G.; OLAZAR, M.; BILBAO, J. Influence of temperature on biomass pyrolysis in a conical spouted bed reactor. Resources, Conservation and Recycling, v.59, p.23-31, 2012. DOI: 10.1016/j. resconrec.2011.04.002.

ASSIS, M.R. de; PROTÁSIO, T. de P.; ASSIS, C.O. de; TRUGILHO, P.F.; SANTANA, W.M.S. Qualidade e rendimento do carvão vegetal de um clone híbrido de Eucalyptus grandis $\mathrm{x}$ Eucalyptus urophylla. Pesquisa Florestal Brasileira, v.32, p.291-302, 2012. DOI: 10.4336/2012.pfb.32.71.291.

ASSOCIAÇÃO BRASILEIRA DE PRODUTORES DE FLORESTAS PLANTADAS. Anuário estatístico da ABRAF 2012: ano base 2011. Brasília: Abraf, 2012. 145p.

BABAÇU: Programa Nacional de Pesquisa. Brasília: Embrapa-DPP; Teresina: Embrapa-UEPAE de Teresina, 1984. 89 p. (Embrapa-UEPAE de Teresina. Documentos, 2).

BURHENNE, L.; MESSMER, J.; AICHER, T.; LABORIE, M.-P. The effect of the biomass components lignin, cellulose and hemicellulose on TGA and fixed bed pyrolysis. Journal of 
Analytical and Applied Pyrolysis, v.10, p.177-184, 2013. DOI: 10.1016/j.jaap.2013.01.012.

CASTRO, A.F.N.M.; CASTRO, R.V.O.; CARNEIRO, A. de C.O.; LIMA, J.E. de; SANTOS, R.C. dos; PEREIRA, B.L.C.; ALVES, I.C.N. Análise multivariada para seleção de clones de eucalipto destinados à produção de carvão vegetal. Pesquisa Agropecuária Brasileira, v.48, p.627-635, 2013. DOI: 10.1590/ S0100-204X2013000600008.

DEMIRBAS, A. Effects of temperature and particle size on bio-char yield from pyrolysis of agricultural residues. Journal of Analytical and Applied Pyrolysis, v.72, p.243-248, 2004. DOI: 10.1016/j. jaap.2004.07.003.

DIAS, J.M.C. de S.; SOUZA, D.T. dos; BRAGA, M.; ONOYOMA, M.M.; MIRANDA, C.H.B.; BARBOSA, P.F.D.; ROCHA, J.D. Produção de briquetes e péletes a partir de resíduos agrícolas, agroindustriais e florestais. Brasília: Embrapa Agroenergia, 2012. 130p. (Embrapa Agroenergia. Documentos, 13).

EMMERICH, F.G.; LUENGO, C.A. Babassu charcoal: a sulfurless renewable thermo-reducing feedstock for steelmaking. Biomass and Bioenergy, v.10, p.41-44, 1996. DOI: 10.1016/0961-9534(95)00060-7.

FERREIRA, E.B.; CAVALCANTI, P.P.; NOGUEIRA, D.A. ExpDes: experimental designs pacakge. Version 1.1.2. 2013. Available at: $<$ http://cran.r-project.org/web/packages/ExpDes/index.html $>$. Accessed on: 14 July 2013.

INSTITUTO BRASILEIRO DE GEOGRAFIA E ESTATÍSTICA. Sistema IBGE de recuperação automática - Sidra: banco de dados agregados. Disponível em: <http://www.sidra.ibge.gov.br/bda/tabela/ listabl.asp? $\mathrm{z}=\mathrm{t} \& \mathrm{o}=29 \& \mathrm{i}=\mathrm{P} \& \mathrm{c}=291>$. Acesso em: 14 jul. 2013.

NEVES, T.A.; PROTÁSIO, T. de P.; COUTO, A.M.; TRUGILHO, P.F.; SILVA, V.O.; VIEIRA, C.M.M. Avaliação de clones de Eucalyptus em diferentes locais visando à produção de carvão vegetal. Pesquisa Florestal Brasileira, v.31, p.319-330, 2011. DOI: 10.4336/2011. pfb.31.68.319.

NOWAKOWSKI, D.J.; BRIDGWATER, A.V.; ELLIOTT, D.C.; MEIER, D.; WILD, P. Lignin fast pyrolysis: results from an international collaboration. Journal of Analytical and Applied Pyrolysis, v.88, p.53-72, 2010. DOI: 10.1016/j.jaap.2010.02.009.

NUNES, C.A.; LIMA, C.F.; BARBOSA, L.C.A.; COLODETTE, J.L.; GOUVEIA, A.F.G. Determination of Eucalyptus spp lignin S/G ratio: a comparison between methods. Bioresource Technology, v.101, p.4056-4061, 2010. DOI: 10.1016/j.biortech.2010.01.012.

PEREIRA, B.L.C.; CARNEIRO, A. de C.O.; CARVALHO, A.M.M.L.; COLODETTE, J.L.; OLIVEIRA, A.C.; FONTES, M.P.F. Influence of chemical composition of Eucalyptus wood on gravimetric yield and charcoal properties. Bioresources, v.8, p.4574-4592, 2013.

PEREIRA, B.L.C.; OLIVEIRA, A.C.; CARVALHO, A.M.M.L.; CARNEIRO, A. de C.O.; SANTOS, L.C.; VITAL, B.R. Quality of wood and charcoal from Eucalyptus clones for ironmaster use. International Journal of Forestry Research, v.2012, p.1-8, 2012. DOI: $10.1155 / 2012 / 523025$.
PLANO de ação para prevenção e controle do desmatamento e das queimadas: cerrado. Brasília: Ministério do Meio Ambiente, 2010. 200p.

PROTÁSIO, T. de P.; COUTO, A.M.; REIS, A.A. dos; TRUGILHO, P.F. Seleção de clones de Eucalyptus para a produção de carvão vegetal e bioenergia por meio de técnicas univariadas e multivariadas. Scientia Forestalis, v.42, p.15-28, 2013a.

PROTÁSIO, T. de P.; COUTO, A.M.; REIS, A.A. dos; TRUGILHO, P.F.; GODINHO, T.P. Potencial siderúrgico e energético do carvão vegetal de clones de Eucalyptus spp. aos 42 meses de idade. Pesquisa Florestal Brasileira, v.33, p.137-149, 2013b. DOI: 10.4336/2013. pfb.33.74.448.

PROTÁSIO, T. de P.; SANTANA, J. de D.P. de; GUIMARÃES NETO, R.M.; GUIMARÃES JÚNIOR, J.B.; TRUGILHO, P.F.; RIBEIRO, I.B. Avaliação da qualidade do carvão vegetal de Qualea parviflora. Pesquisa Florestal Brasileira, v.31, p.295-297, 2011. DOI: 10.4336/2011.pfb.31.68.295.

PROTÁSIO, T. de P.; TRUGILHO, P.F.; CÉSAR, A.A. da S.; NAPOLI, A.; MELO, I.C.N.A. de; SILVA, M.G. da. Babassu nut residues: potential for bioenergy use in the North and Northeast of Brazil. SpringerPlus, v.3, p.1-14, 2014.

R DEVELOPMENT CORE TEAM. R: a language and environment for statistical computing. Vienna: R Foundation for Statistical Computing, 2013. Available at: <http://www.R-project.org/>. Accessed on: 14 July 2013.

REIS, A.A. dos; PROTÁSIO, T. de P.; MELO, I.C.N.A. de; TRUGILHO, P.F.; CARNEIRO, A. de C. Composição da madeira e do carvão vegetal de Eucalyptus urophylla em diferentes locais de plantio. Pesquisa Florestal Brasileira, v.32, p.277-290, 2012. DOI: 10.4336/2012.pfb.32.71.277.

SILVA, J. de C. e; BARRICHELO, L.E.G.; BRITO, J.O. Endocarpos de babaçu e macaúba comparados a madeira de Eucalyptus grandis para produção de carvão vegetal. IPEF, n.34, p.31-34, 1986.

TEIXEIRA, M.A. Babassu - a new approach for an ancient Brazilian biomass. Biomass and Bioenergy, v.32, p.857-864, 2008. DOI: 10.1016/j.biombioe.2007.12.016.

TITILADUNAYO, I.F.; MCDONALD, A.G.; FAPETU, O.P. Effect of temperature on biochar product yield from selected lignocellulosic biomass in a pyrolysis process. Waste and Biomass Valorization, v.3, p.311-318, 2012. DOI: 10.1007/s12649-012-9118-6.

TRUGILHO, P.F.; SILVA, D.A. da. Influência da temperatura final de carbonização nas características físicas e químicas do carvão vegetal de jatobá (Himenea courbaril L.). Scientia Agraria, v.2, p.45-53, 2001.

VIEIRA, R. da S.; LIMA, J.T.; MONTEIRO, T.C.; SELVATTI, T. de S.; BARAÚNA, E.E.P.; NAPOLI, A. Influência da temperatura no rendimento dos produtos da carbonização de Eucalyptus microcorys. Cerne, v.19, p.59-64, 2013. DOI: 10.1590/ S0104-77602013000100008.

YANG, H.; YAN, R.; CHEN, H.; LEE, D.H.; ZHENG, C. Characteristics of hemicellulose, cellulose and lignin pyrolysis. Fuel, v.86, p.1781-1788, 2007. DOI: 10.1016/j.fuel.2006.12.013. 